\title{
Sapta Transformasi IAIN Sorong: Dari Klablim ke Pentas Global
}

\author{
Ismail Suardi Wekke \\ Institut Agama Islam Negeri (IAIN) Sorong, Papua Barat \\ Email: iswekke@gmail.com
}

Sekali lagi, selamat atas alih status. Bukan alih fungsi. STAIN Sorong wujud menjadi IAIN Sorong. Perjalanan dalam meniti IAIN Sorong akan sama menggembirakannya ketika melakukan proses untuk STAIN Sorong ke IAIN Sorong.

Sebelum melanjutkan paparan saya, mari membaca fatihah kepada para perintis dan dosen STAIN Sorong yang telah mendahului, lahum alfatihah. Teringat bagi saya, ada Prof. Saefuddin, Dr. Rais, dan Dr. Abbas. Baru-baru saja, Dr. Saiful. Dua pekan lalu, saya diminta menuliskan alamat saya di Sorong. Lalu, saya tuliskan Jl. Prof. Dr. Saefuddin, dimana jalan kediaman saya memang belum bernama.

Terkait dengan itu, saya ketikkan sapta transformasi. Bisa saja lebih, namun yang terlintas sekilas ketika menerima kabar gembira perpres yang sudah terbit, sebagai berikut:

Pertama, afiliasi. Institusi Agama Islam Negeri (IAIN) Sorong, nama ini perlu disosialisasikan dan ditulisan secara lengkap. Bukan dengan singkatan. Sehingga akan terbaca pada mesin indeksasi dengan nama yang sama.

Soal afiliasi ini perlu keseragaman. Jangan diterjemahkan. Sebagai nama, itulah nama yang tertera di "akte kelahiran", sehingga tidak diperlukan penerjemahan.

Nama perlu digunakan secara konsisten, supaya dalam mesin pencari seperti Google, akan mudah terbaca. Apalagi ada puluhan IAIN sehingga gandingan IAIN dan Sorong, jika mau dikenali oleh mesin, perlu digunakan secara konsisten.

Kedua, re-akreditasi. Surveillance, menjadi syarat utama. Dimana akreditasi yang ada atas nama STAIN Sorong, termasuk di sertifikat dan seluruh perangkat lainnya. Maka, perlu dimohonkan ke BAN-PT untuk dilakukan surveillance terkait dengan perubahan nama untuk status akreditasi dengan nama IAIN Sorong.

Sebelum ini, semua akreditasi baik program studi maupun institusi atas nama STAIN Sorong, termasuk di pangkalan data BAN-PT sekarang ini tetap STAIN Sorong. Maka, langkah harus dilakukan adalah memohon surveillance ke BAN-PT. selanjutnya, BAN-PT akan menerbitkan SK dan sertifikat baru dengan nama IAIN Sorong. Sehingga ketika menerbitkan ijazah dengan menggunakan nama IAIN Sorong, akan sinkron dengan data-data BAN-PT.

Sebagai catatan historis, ada perguruan tinggi setelah beralih status dari STAIN ke IAIN lupa tertinggal untuk melakukan surveillance. Akibatnya, ijazah yang dikeluarkan terkendala dalam pendaftaran ASN bagi alumninya. Tentu ini kita hindari untuk terjadi dalam skala IAIN Sorong.

Akreditasi sudah berbasis daring, maka saatnya menautkan aktivitas tri dharma dengan laman web. Dimana ini akan menjadi rekam jejak dari tri dharma yang dilakukan. Maka, tantangan reakreditasi tidak lagi pada soal penataan infrastruktur saja yang sama pentingnya dengan penataan digitalisasi kampus. 
Ketiga, kelembagaan. Akan ada proses penyusunan dokumen ortaker. Setelah terbitnya peraturan presiden, maka ortaker ini dikoordinasikan dengan Kementerian Agama. Ada waktu yang perlu dilalui seiring dengan penerbitan ortaker. Maka, perlu bersabar sembari terus melakukan koordinasi.

Penamaan fakultas, mengikut kepada keadaan program studi yang sudah ada. Senyampang mengajukan juga perizinan untuk program studi yang belum ada, namun sudah ada ketersediaan sumber daya manusia dan kebutuhan lokal.

Keempat, penyiapan laman web. Termasuk email institusi dan juga perangkat pembelajaran daring.

Laman web www.stainsorong.ac.id akan berubah. Maka, semua jurnal juga akan berubah lagi. Email institusi-pun berubah juga, seperti email: iswekke@ stainsorong.ac.id tidak bisa aktif tentunya. Akan kehilangan data dan juga kontak mulai diulangi kembali.

Apa yang dapat dilakukan? Alamat web ketika menjadi UIN suatu masa akan datang, tidak perlu berubah lagi. Ada kerugian data dan juga aktivitas web yang tidak akan bisa dipindahkan jikalau membuat web baru.

Adakah perangkat pembelajaran daring yang sudah ada? Belum terlihat. Alternatif yang bisa digunakan saat ini dengan menggunakan perangkat pembelajaran daring yang sudah ada dan gratis seperti http://fdi.kuliahdaring.id.

Ini hanya salah satu, platform disiapkan oleh Forum Dosen Indonesia untuk kemudahan pembelajaran. Banyak platform lain, disesuaikan dengan kebiasaan masing-masing dosen.

Kelima, migrasi pangkalan data perguruan tinggi. Saat ini forlap dikti menjadi instrumen tidak saja terkait dengan status kemahasiswaan tetapi juga sampai pada alumni untuk melakukan validasi ijazah.

Maka, sebelum bermigrasi ke status IAIN Sorong dalam pangkalan data perguruan tinggi, perlu kembali dicek terkait dengan dosen dan mahasiswa.

Keenam, atribut organisasi; logo, mars, dan himne. Kita bisa saksikan IAIN Batusangkara, IAIN Bukitinggi, dan UIN Imam Bonjol. Ketiganya menggunakan nuansa lokal dalam membuat logo.

Tidak harus melalui sayembara seperti dilakukan UIN Alauddin Makassar. Sebab bisajadi memantik kontroversi, jikalau ada kemiripan dengan lambing yang memenangkan lomba.

Hanya saja, setelah logo ditetapkan, maka perlu disiapkan logo resmi yang tercantum di website sehingga penggunaan logo seragam untuk keperluan apapun juga.

Kita bisa lihat logo UIN yang bertransformasi di abad 20, semuanya hamper seragam. Maka, saatnya membentuk logo yang memungkinkan cerminan abad 21.

Demikian pula mars dan himne. Perlu dinamis, tidak harus statis sebagaimana ketika hanya dalam bentuk keseragaman IAIN, sebelum pembentukan STAIN di tahun 1997. 
Ketujuh, orientasi perguruan tinggi. Termasuk penyiapan sumber daya manusia. Dengan wujudnya IAIN Sorong, maka dosen didorong untuk melanjutkan studi doktoral. Sementara bagi yang sudah doktor, didampingi untuk guru besar.

Dalam tiga tahun ke depan sudah bisa diajukan untuk perizinan program doktor. Ini jika sudah ada minimal dua guru besar.

Potensi doktor kita ada tiga yang sudah lektor kepala. Ini bisa didampingi untuk ke guru besar dengan program yang terstruktur seperti post-doctoral program, juga pendampingan publikasi ilmiah.

Sementara dua doktor, masing-masing satu lector, dan satu asisten ahli. Dosen yang sementara Pendidikan doktor ada lima orang. Sekarang ada lima doctor, dan yang akan datang empat. Sehingga membuka program studi S-3, sangat memungkinkan dalam dua atau tiga tahun yang akan datang.

STAIN Sorong telah melakukan pelbagai dan ragam aktifitas akademik selama ini. Dengan status IAIN Sorong, maka perlu dipertahankan. Termasuk mulai membentuk iklim akademik dan sehingga bisa wujud atmosfer akademik.

Pelaksanaan pembelajaran dan juga aktivitas pengabdian masyarakat, perlu diarahkan dengan wawasan tata kelola berbasis akreditasi. Sehingga paduan ketiga dharma perguruan tinggi saling terkait.

Satu hal lagi, saatnya melakukan pengantarbangsaan (internasionalisasi) IAIN Sorong. Dengan peraturan Mentri Pendidikan dan Kebudayaan RI No 5 tahun 2020 yang memberikan kesempatan untuk kerjasama global, maka ini menjadi pintu masuk untuk memberikan penguatan internasionalisasi IAIN Sorong.

Sekaligus, akreditasi menjadi sebuah bonus dengan adanya kerjasama global. Selama ini, tidak saja di kalangan warga di luar Tanah Papua, bahkan warga Tanah Papua sendiri mengukuhkan stigma "tertinggal".

Padahal, dalam pelbagai peluang, ada kesempatan untuk bersanding dengan perguruan tinggi lain. Tidak hanya dalam skala nasional, tetapi juga antarbangsa.

Maka, saya teringat pesan allahuyarham Prof. Dr. Saefuddin "interaksi global, akan membawa pemikiran berwawasan global". Walaupun dengan lokasi di bagian timur Indonesia, bukan menjadi alas an bagi kita untuk tidak bisa bersanding dengan perguruan tinggi lain di seluruh dunia.

Ada banyak peluang untuk dikembangkan, terutama dalam kajian Papua yang selama ini sudah diteroka. Namun dalam perspektif kajian keislaman, ada saja ruang-ruang yang dapat diekslporasi sehingga bisa menjadikan IAIN Sorong sebagai pusat kajian Papua.

Tidak lagi relevan senantiasa mengukuhkan stigma tertinggal. Lalu menjadikan Papua sebagai alas n. Perlu langkah demi langkah untuk membangun rekognisi global. Itu bisa dilakukan, jika sejak dini sudah membangun jejaring, bisa dimulai dari Kawasan Asia Tenggara. Selanjutnya mengelola apa yang menjadi kekuatan Asia Tenggara untuk berada di pentas Asia, Australia, Eropa, dan Amerika. 
Kita bisa melewati status sekolah tinggi menjadi institut. Selama empat belas tahun STAIN Sorong adalah masa-masa menjadi pondasi keberadaan IAIN Sorong. Kalua ini tidak dituliskan menjadi catatan sejarah, maka akan hilang.

Saatnya untuk menoleh sejenak. Menuliskan pengalaman masing-masing, dan kemudian mengabadikan cerita ini untuk menjadi penguat jika di masa depan ada tantangan-tantangan hebat yang sementara kita hadapi. Sehingga dari sejarah masa lalu, akan memeperkuat tekad dan upaya kita dalam mengelola IAIN Sorong yang pada saatnya nanti akan menjadi UIN Sorong.

Terima kasih, itu lintasan ide semasa mendengar kabar gembira perpres. Ketikan demi ketikan ini tidak terbangun secara komprehensif, ada ruang yang menjadi kesempatan kita untuk didiskusikan dan dikembangkan secara lengkap lagi.

Sekali lagi, selamat atas alih status, jayalah IAIN Sorong. Pasti, pasti, pasti bisa... 